\title{
PENGEMBANGAN MEDIA PEMBELAJARAN MATEMATIKA TRIGO FUN BERBASIS GAME EDUKASI MENGGUNAKAN ADOBE ANIMATE PADA MATERI TRIGONOMETRI
}

\author{
Fibby Syaeful Abdullah $^{\mathbf{1}}$, Tri Nova Hasti Yunianta ${ }^{2}$ \\ ${ }^{1,2}$ Pendidikan Matematika, Universitas Kristen Satya Wacana \\ E-mail:202015004@student.uksw.edu ${ }^{l)}$ \\ trinova.yunianta@staff.uksw.ed ${ }^{2}$
}

Received 20 October 2018; Received in revised form 16 November 2018; Accepted 30 December 2018

\begin{abstract}
This study aims to develop a mathematics education game on Trigonometry material. The type of this research is research and development $(R \& D)$ using the ADDIE development model. The steps consist of: (1) Analysis, (2) Design, (3) Development, (4) Implementation, (5) Evaluation. Media validation is carried out by material experts and media experts. Material validity reached $78 \%$ in the good category and media validity reached $96.43 \%$ in the very good category. Media trials were conducted at SMK Negeri 2 Salatiga class XI TEI A on 35 students and produced a practical index of $98 \%$ in the very good category. The results of media implementation showed that after using the media, experiencing an increase in learning outcomes of 1.1814 was included in the high increase category. Based on the results of the study it can be concluded that the media mathematics education game is valid, practical, and effective to use.
\end{abstract}

Keywords: ADDIE; Adobe Animate; media educational game; trigonometry.

\section{PENDAHULUAN}

Zaman sekarang teknologi berkembang begitu pesat dan hampir disemua bidang. Salah satunya yaitu perkembangan teknologi pada pendidikan. Adanya perkembangan teknologi dan komunikasi akan menjadikan pendidikan lebih maju dan berkembang. Melalui hal tersebut teknologi memiliki posisi yang penting dalam perkembangan pendidikan saat ini yaitu melalui adanya media yang dapat membantu dalam proses pembelajaran

Media pembelajaran merupakan alat yang dapat membantu proses belajar dan mengajar serta juga memiliki fungsi untuk memperjelas makna yang disampaikan dalam proses pembelajaran, sehingga tujuan pembelajaran dapat tercapai (Kustandi, 2013: 8). Media pembelajaran memiliki dua peranan penting dalam proses pembelajaran antara laian: (1) media sebagai alat bantu mengajar, (2) media sebagai sumber belajar yang diinginkan sendiri oleh siswa secara mandiri (Rusman, 2012: 140)

Perkembangan media pembelajaran mengikuti arus teknologi. Teknologi modern yang saat ini dimanfaatkan dalam proses belajar mengajar adalah teknologi micro processor atau dikenal dengan teknologi komputer. Salah satu media pembelajaran yang dapat dikembangkan melalui teknologi komputer adalah media game edukasi. Game edukasi adalah permainan yang bersifat mendidik. Fuqoha (2015: 6) mengatakan bahwa melalui game siswa akan mendapat sesuatu yang menyenangkan, saat siswa merasa senang maka siswa akan membentuk memori baru.

Handphone merupakan hasil
perkembangan teknologi yang
penggunanya yang tidak lepas dari
aktivitas sehari-hari. Handphone mudah
dioperasikan serta juga mudah untuk

\section{4 | AKSIOMA}

Jurnal Pendidikan Matematika FKIP Univ. Muhammadiyah Metro 
didapatkan. Saat ini handphone semakin canggih dengan memiliki berbagai macam sistem operasi diantaranya Symbian, Blackberry, Windows Phone, Iphone dan Android. Handphonehandphone canggih tersebut dikenal dengan nama Smartphone.

Smartphone adalah device yang dapat digunakan dalam berbagai aktivitas, tidak hanya dalam komunikasi, tetapi juga terdapat fungsi PDA (Personal Digital Assistant) dan berkemampuan seperti komputer canggih (Afifudin, 2013: 2). Survei terbaru yang dilakukan oleh Lembaga Riset Digital Marketing Emareter diperkirakan pengguna smartphone di Indonesia mencapai lebih dari 100 juta orang (Kementerian Komunikasi dan Informatika Republik Indonesia, 2015). Banyaknya pengguna smartphone dapat menjadi peluang untuk mengembangkan media pembelajaran yang modern. Pembelajaran dengan smartphone akan lebih mudah dilakukan dan penggunaannya lebih praktis. Maka dari itu itu smartphone dapat menjadi modal pembelajaran yang efektif dan praktis untuk penggunaan game edukasi. Banyak software yang dapat digunakan untuk membuat game seperti RPG Maker, Adobe Animate, Adobe Flash, Unity 3D, Game Maker, Construck 2.

Software yang digunakan adalah Adobe Animate yang merupakan versi paling baru dari Adobe Flash. Adobe Animate adalah aplikasi desain grafis yang sering digunakan oleh desainerdesaner untuk membuat karya profesional, khususnya dalam bidang animasi (Hanafi, 2015: 51). Adobe Animate dapat beroperasi pada Microsoft Windows dan Mac Os, serta produk yang dihasilkan oleh Adobe Animate dapat beroperasi pada sistem Windows, Mac, Xbox 360, iPad, iPhone, dan Android. Oleh karena itu, menggunakan Adobe Animate dapat membuat game edukasi sebagai media pembelajaran matematika yang menarik dan dapat dimainkan pada smartphone.

Penelitian ini menggunakan Metode Drill. Metode Drill ialah salah satu cara mengajar untuk membentuk kebiasaan baik dan menghasilkan suatu ketangkasan, keterampilan, kesempatan dan ketepatan (Wahyuni, 2016: 401). Materi yang diterapkan dalam media game edukasi ini adalah Trigonometri. Trigonometri merupakan materi yang sulit dipahami oleh siswa SMK dilihat dari hasil belajarnya yang masih tergolong rendah (Khotimah, 2016: 2158). Lebih lanjut, dalam penelitian Sultoni (2018: 860) mengatakan bahwa Trigonometri merupakan materi ajar yang menduduki peringkat atas kesulitan guru dalam pembelajaran.

Penelitian game edukasi sebagai media pembelajaran telah dilakukan oleh beberapa peneliti. Diantaranya adalah penelitian yang dilakukan oleh Utomo (2016). Produk yang dihasilkan adalah media pembelajaran matematika berbasis game edukasi flash yang dapat dimainkan dioperasikan pada komputer. Hasil penelitianya menyimpulkan bahwa media pembelajaran ini valid, praktis dan efektif digunakan untuk meningkatkan kemampun siswa dalam menentukan akar akar dari persamaan kuadrat.

Penelitian yang lainya dilakukan oleh Hardianto (2018). Produk yang dihasilkan adalah game edukasi berjenis RPG yang dapat dioperasikan pada komputer. Hasil penelitianya menyimpulkan bahwa bahwa game edukasi "Petualangan Arka" valid, praktis, dan efektif untuk digunakan sebagai media pembelajaran materi bangun datar segi empat. Penelitian lain dilakukan oleh Marendra dkk (2016). Hasil penelitianya menyimpulkan bahwa game edukasi dapat dijadikan 
media bermain dan belajar siswa khususnya matematika, memberikan nuansa yang menyenangkan pada anak dengan konsep bermain dan belajar, merupakan jenis serta inovasi baru dalam dunia pendidikan sebagai alat peraga bantu anak agar terhindar dari math anxiety.

Salah satu solusi untuk membuat belajar matematika menjadi menyenangkan adalah dengan membuat sebuah media pembelajaran yang menyenangkan serta menarik untuk digunakan. Tujuan dari penelitian ini adalah untuk mengembangkan media pembelajaran matematika berbasis game edukasi pada materi Trigonometri bagi siswa kelas XI SMK yang valid, praktis, dan efektif. Diharapkan media ini dapat menjadi sarana bermain dan belajar serta dapat menjadi media berlatih siswa mengerjakan soal-soal agar memperkuat pemahaman konsep Trigonometri.

Terdapat pembaharuan penelitian ini dengan peneliti-peneliti sebelumnya. Hasil dari penelitian ini adalah game edukasi yang dapat dioperasikan pada perangkat smartphone android.

\section{METODE PENELITIAN}

Penelitian ini merupakan penelitian dan pengembangan atau Research and Development (R\&D). Hasil dari penelitian ini adalah sebuah produk media pembelajaran matematika berupa game edukasi yang dibuat menggunakan software Adobe Animate CC 2018 pada materi Trigonometri. Penelitian ini dilaksanakan mulai tanggal 15 Januari 2018 sampai 10 September 2018. Subjek penelitian ini adalah siswa kelas XI TEI A SMK Negeri 2 Salatiga dengan jumlah 35 siswa.

Model yang digunakan untuk pengembangan media pembelajaran ini adalah model ADDIE yang mempunyai tahap-tahap sebagai berikut: (1) tahap analysis meliputi analisis kerja dan analisis kebutuhan, (2) tahap design meliputi penataan materi yang digunakan, penyusunan materi serta penyampaianya dan pendataan bahanbahan yang dibutuhkan dalam pengembangan media, (3) tahap development terdiri dari pembuatan media dan pemberian nilai yang dilakukan oleh ahli, (4) tahap implementation meliputi penggunaan media sebagai media pembelajaran, (5) tahap evaluation diperlukan untuk mengevaluasi media yang sudah dikembangkann.

Instrumen pengumpulan data yang digunakan terdiri dari: (1) lembar penilaian ahli, (2) lembar penilaian kepraktisan (3) lembar pretest dan posttest, (4) lembar pendapat siswa. Lembar penilaian ahli diberikan kepada ahli materi (pakar dalam matematika) dan ahli media (pakar dalam media pembelajaran) untuk memvalidasi media pembelajaran yang telah dibuat. Lembar kepraktisan diberikan kepada guru untuk mengetahui apakah media sudah layak disebut praktis atau belum. Data yang diperoleh dalam bentuk skala Likert (interval 1 sampai 5) kemudian dihitung persentase dari keseluruhan aspek. Perhitungan indeks kevalidan dan kepraktisan dihitung menggunakan rumus:

$$
\mathrm{P}(\mathrm{s})=(\mathrm{S} / \mathrm{N}) \times 100 \%
$$

Keterangan:

$\mathrm{P}(\mathrm{s}) \quad=$ persentase sub variabel

$\mathrm{S} \quad=$ jumlah skor tiap sub

$\mathrm{N} \quad=$ jumlah skor maksimum

Selanjutnya hasil perhitungan diklarifikasi sesuai kategori pada Tabel 1 .

\section{$436 \mid$ AKSIOMA}


ISSN 2089-8703 (Print) Vol. 7, No. 3 (2018) 434-443

ISSN 2442-5419 (Online)

Tabel 1. Kriteria Penilaian

\begin{tabular}{ccc}
\hline No & Interval & Keterangan \\
\hline 1 & $84 \% \leq$ skor $\leq 100 \%$ & Sangat Baik \\
2 & $68 \% \leq$ skor $<84 \%$ & Baik \\
3 & $52 \% \leq$ skor $<68 \%$ & Cukup \\
4 & $36 \% \leq$ skor $<52 \%$ & Kurang \\
5 & $20 \% \leq$ skor $<36 \%$ & Sangat \\
& & Kurang \\
\hline
\end{tabular}

Adapun untuk menguji keefektifan media menggunakan pretest, posttest dan lembar pendapat siswa, sebelum penggunaan media dilakukan pretest, setelah penggunaan media dilakukan posttest dan pengisisan lembar pendapat siswa. Soal pretest dan posttest masing-masing berjumlah 10 soal dengan bobot yang seimbang. Sebelum digunakan, soal pretest dan posttest divalidasi oleh guru supaya soal sesuai dengan materi. Keefektifan medfia diperoleh dari data hasil belajar siswa serta lembar pendapat siswa. Cara mengetahui respon siswa setelah menggunakan media, digunakanlah lembar pendapat siswa. Data hasil belajar siswa sebelum dan sesudah menggunakan media dianalisis menggunakan N-Gain. Selanjutnya hasil perhitungan diklarifikasi sesuai dengan kategori penilaian pada Tabel 2.

Rumus $\mathrm{N}$-Gain sebagai berikut: $N$ Gain $=\frac{\text { skor posttest }- \text { skor pretest }}{\text { skor maksimum }- \text { skor pretest }}$

Tabel 2. Pedoman Kategori N-Gain

\begin{tabular}{cc}
\hline Skor N-Gain & Kategori \\
\hline $\mathrm{G} \geq 0,70$ & Tinggi \\
$0,3 \leq \mathrm{G}<0,7$ & Sedang \\
$\mathrm{G}<0,3$ & Rendah \\
\hline
\end{tabular}

Sumber: Winarto (2018)

\section{HASIL PENELITIAN DAN PEMBAHASAN}

\section{Tahap Analysis (Analisis)}

Tahap analisis ini memperoleh hasil bahwa kurikulum yang digunakan kelas XI TEI A adalah kurikulum 2013 revisi 2017. Materi Trigonometri merupakan materi wajib yang diajarkan pada kelas $\mathrm{X}$ semester 2 yang terdiri dari beberapa Kompetensi Dasar (KD) yaitu: (1) rasio trigonometri (2) sudutsudut yang berelasi (3) aturan sinus dan cosinus, (4) fungsi trigonometri dengan menggunakan lingkaran.

Media yang dibutuhkan adalah media pembelajaran berbasis game edukasi yang berisi latihan-latihan soal atau evaluasi yang dikemas dalam bentuk permainan klasik yang bersifat memberikan tantangan pada siswa. Media diharapkan dapat ,mewujudkan pembelajaran matematika yang menarik, menyenangkan dan praktis.

\section{Tahap Design (Desain)}

Tahap desain merupakan tahap inti dari penelitian pengembangan dimana media yang dikembangkan dikerjakan dalam tahap ini. Beberapa hal yang didesain pada tahap ini antara lain: (1) game yang dibuat dalam media; (2) latar atau tema game, (3) karakter khas pada game, (4) cara kerja game, (5) penentuan nama media.

Game ini menggunakan tema pemandangan pantai. Terdapat 2 pilihan permainan dalam media ini. Materi meliputi sudut-sudut yang berelasi, aturan sinus dan aturan cosinus. Karakter utama dari game ini adalah kepiting yang bernama Trigo. Trigo merupakan kependekan dari Trigonometri. Trigo merupakan master dari Trigonometri yang akan memberikan tantangan-tantangan pada pemain. Tampilan pada game bernuansa santai dan menyenangkan diiringi musik yang lucu. Oleh karena itu game ini diberi nama Trigo Fun.

Tahap Development (Pengembangan)

Pengembangan game edukasi ini menggunakan software Adobe Animate CC 2018. Adobe Animate merupakan software grafis yang digunakan untuk membuat beragam animasi dan game modern. Untuk tampilan button dan 
berbagi gambar pada game dibuat menggunakan Coreldraw 2017, sedangkan materi dan pilihan jawaban dibuat menggunakan Microsoft Office Power Point 2016. Halaman pembuka memiliki tampilan yang dapat dilihat pada Gambar 1. Pada halaman ini pemain diminta untuk mengisi identitas diri, setelah itu menekan tombol "OK" yang berada pada ujung kanan bawah untuk menuju ke menu utama.

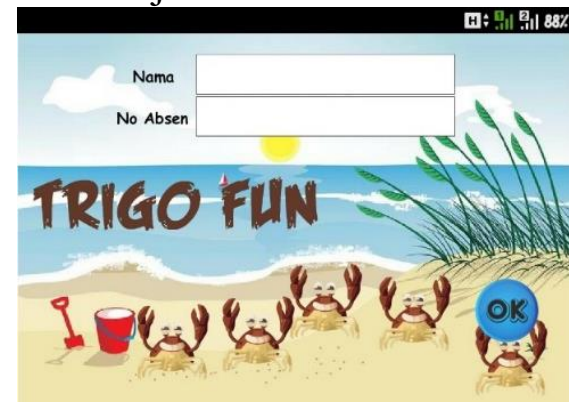

Gambar 1. Tampilan Halaman Awal

Setelah menekan tombol "OK" maka akan tampil menu utama pada game edukasi ini. Tampilan ini berisi 5 menu utama yaitu indikator, tujuan, tentang saya, main, dan keluar. Tampilan menu utama dapat dilihat pada Gambar 2.

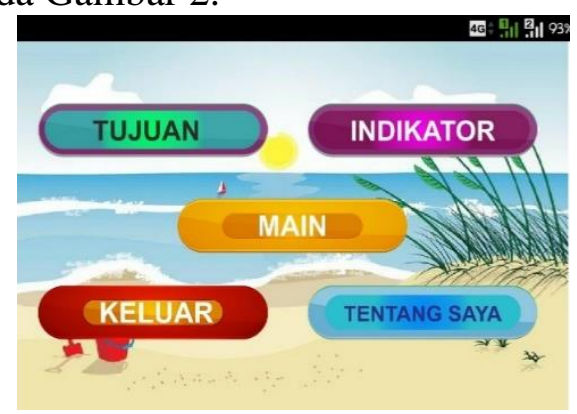

Gambar 2. Tampilan Menu Utama

Tampilan halaman tujuan, indikator dan tentang saya dapat dilihat pada Gambar 3. Halaman Tujuan, Indikator, dan Tentang Saya masing masing memiliki tombol kembali yang berbentuk panah melengkung. Apabila ditekan akan kembali ke menu utama.

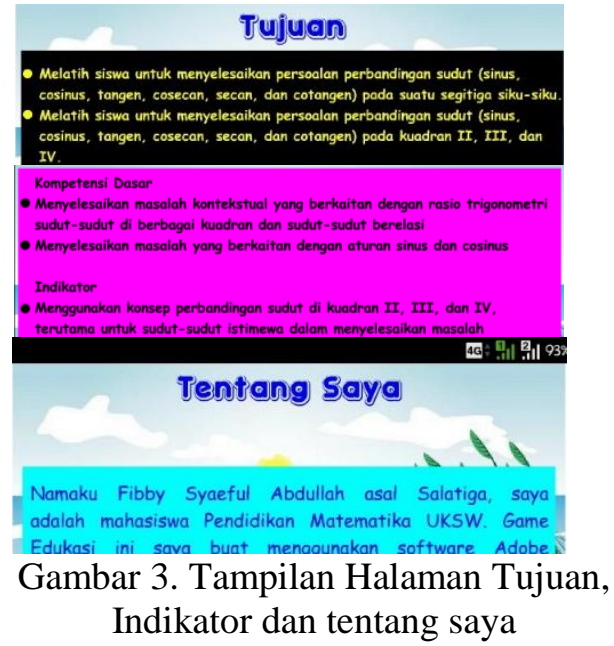

Tombol keluar berfungsi untuk keluar dari aplikasi. Setelah tombol keluar ditekan akan muncul menu kecil. Menu ini dapat dilihat pada Gambar 4.

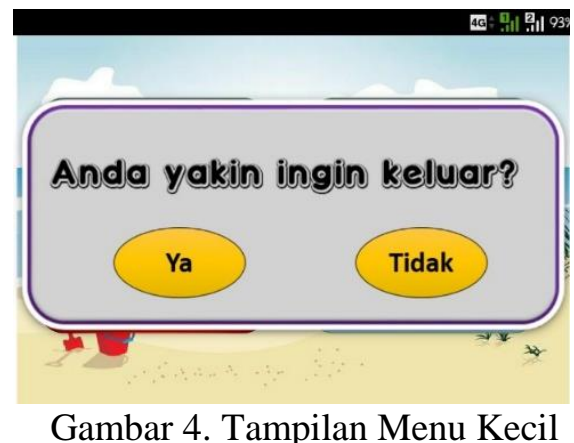

Menu kecil pada Gambar 4.6 apabila ditekan tomboil "Tidak" maka akan kembali ke menu utama, tapi apabila ditekan tombol "Ya" maka akan otomatis keluar dari game edukasi ini.

Jika ditekan tombol main maka akan menuju di halaman perkenalan kepiting yang bernama Trigo. Kepiting ini akan memperkenalkan identitasnya, kemudian memberikan tantangan kepada pemain. Apabila pemain menerima tantanganya maka pemain harus menekan tombol "Ok Siap" dan otomatis menuju halaman pilihan tantangan. Halaman perkenalan karakter dan halaman pilihan tantangan yang dapat dilihat pada Gambar 5. 


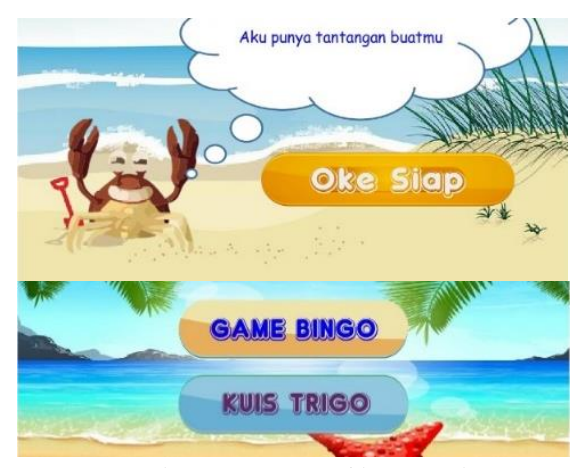

Gambar 5. Tampilan Halaman Perkenalan Menu Kecil

Pemain bebas memilih mana tantangan yang terlebih dahulu akan dihadapi. Setiap tantangan memiliki aturan main. Tampilan aturan main dan tampilan Game Bingo dapat dilihat pada Gambar 6.

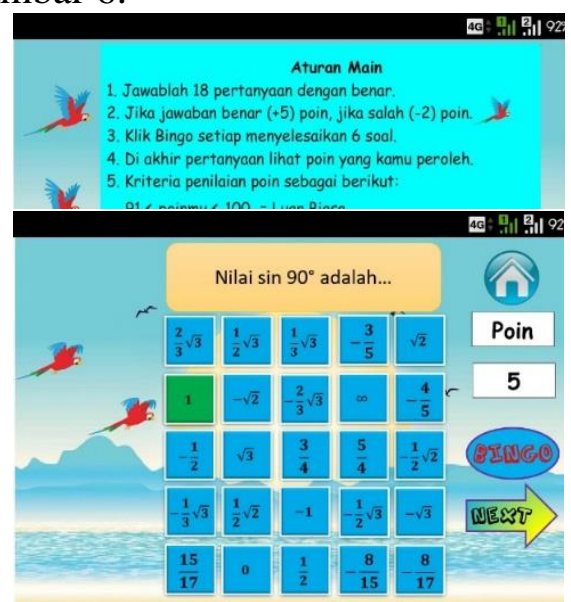

Gambar 6. Tampilan Game Bingo dan Aturan Mainnya

Aturan main Kuis Trigo berbeda dengan aturan main Game Bingo. Aturan main dan tampilan Kuis Trigo dapat dilihat pada Gambar 7. Tampilan Game Bingo dan Kuis Trigo mempunyai beberapa tombol yang mempunyai fungsi masing-masing. Bentuk tombol-tombol ini dibuat sesuai dengan fungsinya sehingga mempermudah pemain untuk mengoprasikanya. Terdapat dua kotak putih yang masing-masing berfungsi untuk tempat tulisan "Poin" dan untuk menampilkan poin yang pemain peroleh.

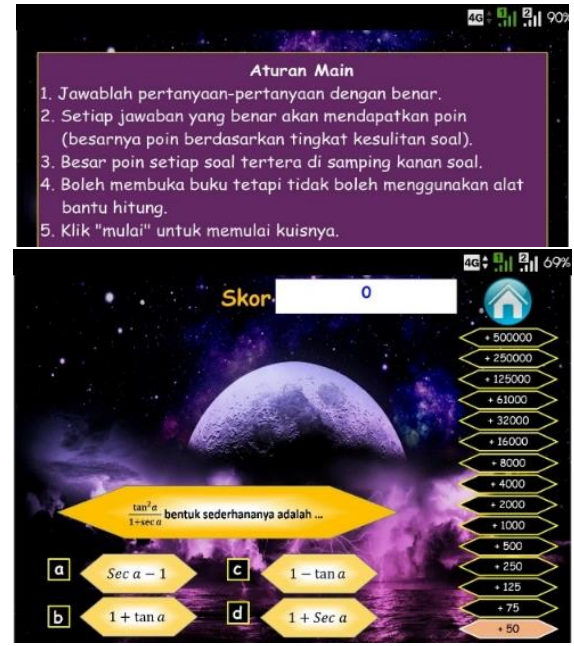

Gambar 7. Tampilan Kuis Trigo dan

Aturan Mainnya

Game yang telah dikembangkan selanjutnya dinilai oleh ahli media dan ahli materi. Penilaian ini bertujuan untuk mendapatkan kritik serta saran yang berguna dalam perbaikan media sebelum diterapkan dalam pembelajaran. Hasil penilaian ahli materi diperoleh skor rata-rata 3,9 dengan persentase kevalidan $78 \%$. Adapun hasil penilaian ahli media diperoleh sekor rata-rata sebesar 4,82 dengan persentase $96,43 \%$.

Ahli materi dan ahli media menyatakan bahwa media game edukasi sudah layak untuk digunakan dengan revisi. Sebelum melakukan tahap implementasi, media direvisi sesuai dengan kritik dan saran.

\section{Tahap Implementation (Implementasi)}

Media ini telah diujicobakan kepada 35 siswa kelas XI SMK Negeri 2 Salatiga selama 2 pertemuan pada tanggal 3 September 2018 dan tanggal 6 September 2018.Masing-masing pertemuan dilakukan selama 2 jam pelajaran. Langkah pertama proses implementasi yaitu dengan mencari tahu pemahaman awal siswa sebelum menggunakan media dalam belajar. Langkah selanjutnya yaitu penerapan media game edukasi kepada siswa yang berfungsi sebagai latihan soal pada 
materi Trigonometri. Langkah selanjutnya adalah memberikan posttest untuk mengetahui pemahaman siswa setelah menggunakan media game edukasi, dari perbandingan hasil pretest dan posttest akan diketahui pengaruh yang diperoleh dari penggunaan media pembelajaran.

\section{Tahap Evaluation (Evaluasi)}

Tujuan dari tahap evaluasi yaitu untuk mengetahui kelemahan dari game edukasi matematika, hasil belajar dan susunan rencana dalam pembelajaran. Hasil dari tahap ini dijadikan dasar untuk perbaikan game edukasi matematika. Keefektifan media game edukasi matematika diperoleh dari pretest, posttest, dan lembar pendapat siswa. Nilai pretest dan posttest siswa kelas XI TEI A SMK Negeri 2 Salatiga dijelaskan pada Tabel 3.

Tabel 3. Nilai Pretest dan Posttest

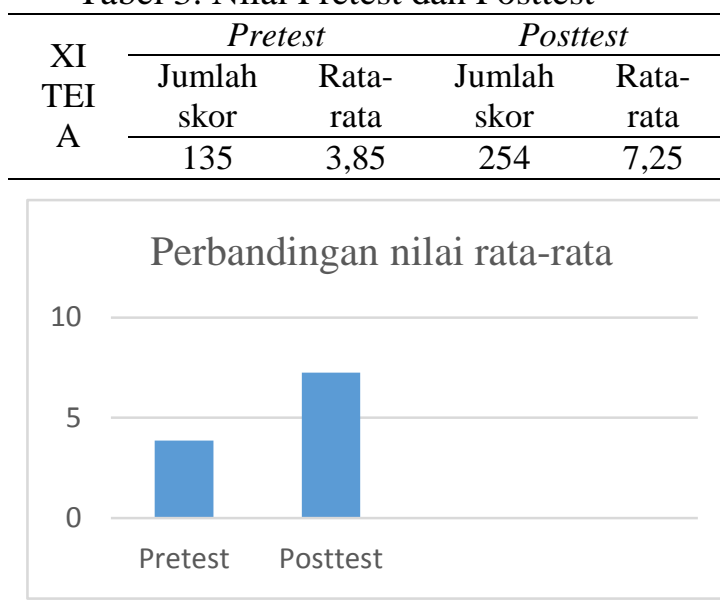

Gambar 8. Grafik Perbandingan Nilai

Berdasarkan penghitungan menggunakan $\mathrm{N}$-Gain diperoleh hasil belajar kelas XI TEI A mengalami peningkatan sebesar 1,1814. Hasil tersebut menunjukan bahwa media game edukasi matematika efektif bagi siswa karena terjadi peningkatan yang signifikan setelah menggunakannya.

Hasil analisis pendapat siswa menunjukkan bahwa media game edukasi membantu siswa dalam belajar materi Trigonometri. Desain yang menarik dan mudah dipahami. Game yang rapi, ringkas, mudah dibawa, dan mudah untuk diakses atau dimainkan. Secara keseluruhan media game edukasi mendapat respon positif dari siswa. . Salah satu respon siswa yaitu game mempunyai tampilan yang menarik, mudah digunakan, menarik minat belajar dan setuju apabila disusun media materi matematika yang lain untuk melatih pengetahuan dan keterampilan siswa.

Hasil validasi instrumen pretest dan posttest menyatakan bahwa: (1) antara soal pretest dan posttest seimbang, (2) Kompetensi Dasar sesuai Standar Kompetensi, (3) indikatorindikator telash sesuai dengan Kompetensi Dasar, (4) petunjuk pengerjaan singkat dan jelas, (5) waktu pengerjaan sesuai dengan jumlah soal, materi soal cukup beragam melibatkan langkah-langkah yang bervariasi, (6) soal cukup baik dan dapat mengukur setiap kompetensi. Hasil uji validitas dari aspek media menghasilkan indeks kevalidan sebesar 96,43\% termasuk dalam kategori sangat baik. Hal ini dikarenakan media memiliki kelebihan diantaranya memiliki tampilan yang menarik, membuat siswa belajar lagi dalam menyelesaikan masalah, dan media dapat digunakan di semua smartphone android secara offline.

Hasil uji validitas dari aspek materi menghasilkan indeks kevalidan sebesar $78 \%$ dan termasuk dalam kategori baik, hal ini dikarenakan materi dalam media memiliki cakupan yang sesuai KD, runtut, keberagaman soal. Hal ini menunjukan bahwa media game edukasi valid untuk digunakan.

Hasil uji kepraktisan diperoleh persentase $98, \%$ dengan skor rata-rata 4,9 termasuk dalam kategori sangat baik. Hal ini dikarenakan media ini berwujud software sehingga mudah dibawa dan dapat digunakan dimana saja saat membawa smartphone serta

\section{0 | AKSIOMA}

Jurnal Pendidikan Matematika FKIP Univ. Muhammadiyah Metro 
dapat digunakan berulang-ulang sehingga membuat media menjadi praktis. Hasil ini memperkuat kesimpulan yang dinyatakan oleh Yustin, dkk (2016), bahwa pengembangan media pembelajaran berbasis game edukasi sebagai media alternatif dalam pembelajaran dan dapat dijadikan media bermain dan belajar yang praktis khususnya matematika.

Hasil uji keefektifan media diambil dari hasil pretest dan posttest yang dianalisis kemudian dihitung peningkatanya menggunakan rumus $\mathrm{N}$ Gain. Berdasarkan hasil perhitungan mnggunakan rumus $N$-Gain kelas XI TEI A mengalami peningkatan sebesar 1,1814 yang termasuk dalam kategori peningkatan tinggi. Hasil pretest dan posttest terdapat pada Tabel 4.

Tabel 4. Rata-Rata Peninngkatan Nilai Siswa

\begin{tabular}{ccccc}
\hline Uji & $\begin{array}{c}\text { Jumla } \\
\text { h Skor }\end{array}$ & $\begin{array}{c}\text { Rata } \\
- \\
\text { Rata }\end{array}$ & $\begin{array}{c}\text { N- } \\
\text { Gain }\end{array}$ & $\begin{array}{c}\text { Kategor } \\
\mathbf{i}\end{array}$ \\
\cline { 1 - 3 } Pretest & 135 & 3,85 & 1,181 & Tinggi \\
\cline { 1 - 3 } $\begin{array}{c}\text { Posttes } \\
t\end{array}$ & 254 & 7,25 & 4 & \\
\end{tabular}

Peningkatan siswa kelas XI TEI A termasuk dalam kategori tinggi setelah menggunakan media game edukasi matematika. Oleh karena itu, dapat disimpulkan bahwa media game edukasi matematika pada materi Trigonometri efektif digunkana sebagai media pembelajaran.

Berdasarkan hasil analisis lembar pendapat siswa diperoleh : (1) secara umum media game edukasi Trigo Fun memiliki keunggulan dari segi tampilan game yang lebih menarik serta diringi dengan musik sehingga tidak membosankan, (2) praktis digunakan karena berwujud software yang terinstal pada smartphone sehinga dapat dimainkan sewaktu-waktu, (3) dapat menjadi alternatif belajar sehingga belajar tidak hanya dari buku-buku saja, (4) mudah digunakan karena petunjuknya jelas. Hal ini sesuai dengan penelitian yang dilakukan oleh Utomo (2016) dan Winarto (2018)

Namun demikian juga ada yang berpendapat bahwa media game edukasi matematika kurang baik karena mudah dihafal kunci jawabanya, lebih baik soal dalam game dibuat acak. Sebagian besar siswa setuju apabila game edukasi matematika dikembangkan juga dalam materi yang lain karena dapat mempermudah siswa dalam belajar sekaligus bermain. Hasil analisis lembar pendapat siswa didapati bahwa siswa memberikan respon baik dan mendukung terhadap penggunan media game edukasi.

Berdasarkan seluruh masukan dari siswa akan menjadi dasar revisi dan penyempurnaan dari game edukasi matematika. Secara keseluruhan respon siswa sangat positif dan dapat disimpulkan bahwa media game edukasi matematika layak untuk digunakan sebagai media pembelajaran, latihan soal, dan suplemen bagi siswa untuk belajar.

Hasil observasi selama penelitian dan pengembangan media game edukasi matematika dilakukan peneliti memperoleh beberapa penemuan yaitu secara umum siswa tertarik dan antusias dengan adanya game edukasi karena menarik, tidak membosankan dan menjadi ajang persaingan dalam mengerjakan soalsoal dalam game. Menurut pendapat guru, dengan adanya game edukasi matematika yang dapat dimainkan di smartphone dapat menambah manfaat smartphone sebagai media untuk belajar siswa.

\section{KESIMPULAN DAN SARAN}

Berdasarkan hasil penelitian disimpulkan bahwa media game edukasi matematika sebagai media pembelajaran siswa pada materi 
Trigonometri valid, efektif dan praktis digunakanuntuk meningkatkan hasil belajar siswa dalam menyelesaikan permasalahan Trigonometri. Hasil validasi menunjukan aspek media memperoleh indeks kevalidan sebesar 96,43\% termasuk dalam kategori sangat baik dan aspek materi memperoleh indeks kevalidan sebesar $78 \%$ yang termasuk dalam kategori baik. Hasil uji kepraktisan diperoleh persentase 98,\% dengan skor rata-rata 4,9 termasuk dalam kategori sangat baik, sehingga media pembelajaran game edukasi Trigo Fun layak untuk digunakan dalam proses pembelajaran.

Berdasarkan kesimpulan di atas, disarankan beberapa hal agar media game edukasi dapat dikembangkan lebih lanjut untuk materi lainnya, konten materi pembelajaran game edukasi untuk materi Trigonometri dapat diperdalam lagi, game edukasi dapat dikembangkan lagi pada mata pelajaran lain, penggunaan game edukasi tidak hanya sebagai sarana belajar mandiri tetapi juga sebagai sarana belajar terimbing disekolah, game edukasi untuk dikembangkan lagi khususnya dalam hal pengacakan soal agar siswa tidak dapat menghafal pola jawaban sehingga dapat digunakan menjadi media ulangan atau kuis untuk memperoleh hasil belajar siswa.

\section{DAFTAR PUSTAKA}

Afifudin. (2013). Pengembangan Apikasi Mobile Learning Pada Smartphone Berbasis Android. Skripsi: Yogyakarta

Fuqoha, A. A. N. (2015). Pengembangan Game RPG (Role Play Game) Sebagai Media Pembelajaran Berbasis Guided Inquiry Untuk Siswa Smp Kelas VII. Thesis: Yogyakarta.
Hanafi, M. I, Budiman, A., \& Nugroho A. A. (2015). Game Edukasi Tebak Gambar Bahas Jawa Menggunakan Adobe Flash CS6 Berbasis Android. Jurnal Sisfotek Global. Vol.5, No. 2, Hal 50-53.

Hardianto, T. A. (2018). Pengembangan Game Edukasi Bangun Datar Segi Empat Dengan Software RPG Maker Bagi Siswa Kelas VII SMP. Skripsi: Salatiga.

Kementerian Komunikasi dan Informatika Republik Indonesia. (2015). Indonesia Raksasa Teknologi Digital Asia. https://www.kominfo.go.id/conten t/detail/6095/indonesia-raksasateknologi-digital-asia/0/sorotan media. diakses 2 Februari 2018.

Khotimah, K., Ipung, Y., \& Rahardjo, S. (2016). Penerapan Pembelajaran Inkuiri Untuk Meningkatkan Hasil Belajar Trigonometri Pada Siswa Kelas X. Jurnal Pendidikan Teori, Penelitian dan Pengembangan. Vol. 1, No. 11, Hal 2158-2162.

Kustandi, C. (2013). Media Pembelajaran Manual dan Digital. Bogor: Ghalia Indonesia.

Marendra, R., Hasyim, N., \& Taufik, M. (2016). Perancangan Game Edukasi Berbasis Matematika Untuk Meningkatkan Minat Belajar Anak Sekolah Dasar. Repositori UDiNus. Vol. 2, No. 2, Hal 1-11.

Rusman. (2012). Belajar dan Pembelajaran Berbasis Komputer. Bandung: Alfabeta.

Sultoni, A. (2018). Pembelajaran Trigonometri Materi Menentukan Tinggi Suatu Benda Berbantuan Klinometer Fleksibel. Prosiding Seminar Nasional Matematika. Vol. 2, No. 1, Hal 860-869.

Utomo. (2016). Pengembangan Media Pembelajaran Matematika Pada 
ISSN 2089-8703 (Print) Vol. 7, No. 3 (2018) 434-443

ISSN 2442-5419 (Online)

Materi Persamaan Kuadrat Menggunakan Adobe Flash CS6. Skripsi tidak diterbitkan: UKSW. Salatiga.

Wahyuni, N. (2016). Penggunaan Metode Drill Dalam Pembelajaran Matematika. Prosiding Seminar Nasional. Vol. 2, No. 1, Hal 399406.

Winarto, A. C. W. E. (2018). Pengembangan Mobile Learning Matematika Sebagai Suplemen Belajar SMA Kelas XI Pada Materi Irisan Kerucut. Jurnal
Pendidikan Matematika. Vol. 2, No. 1. Hal 32-44.

Yustin, J. A., Sujaini, H., \& Irwansyah, M. A. (2016). Rancang Bangun Aplikasi Game Edukasi Pembelajaran Matematika Menggunakan Construct 2. Jurnal Sistem Dan Teknologi Informasi (Justin). Vol. 1, No 1, Hal 1-5. 